\title{
THE USE OF STENTS IN THE TREATMENT OF TRAUMATIC INTIMAL FLAPS: CASE REPORT
}

\author{
Nelson Wolosker, Kenji Nishinari, Livio Nakano, Alexandre Maieira Anacleto, \\ and Pedro Puech-Leão
}

RHCFAP/3047

WOLOSKER N et al. - The use of stents in the treatment of traumatic intimal flaps: case report. Rev. Hosp. Clín. Fac. Med. S. Paulo 56(4):119-122, 2001.

Treatment of arterial traumatic intimal lesions is controversial due to its unknown natural history. Current therapeutical options include arterial reconstruction and clinical observation. The idea of using stents to correct intimal flaps is based on their use to correct dissections, flaps, and arterial irregularities after angioplasty.

We report the successful treatment of a traumatic intimal flap of the superficial femoral artery, caused by gunshot trauma, with a Palmaz stent in the acute period. One year after the operation, a duplex scan revealed normal flow in the artery and complete exclusion of the intimal flap; distal pulses were palpable, and the patient was completely asymptomatic.

DESCRIPTORS: Stents. Femoral artery injuries. Vascular trauma. Minimally invasive techniques. Palmaz stent.

The routine use of duplex scans in arterial trauma has improved the diagnosis of asymptomatic arterial lesions. Intimal flap is one of the most frequent types of occult arterial trauma. Treatment of traumatic intimal lesions is controversial due to its unknown natural history. Current therapeutical options include arterial reconstruction and clinical observation ${ }^{\mathbf{1}}$.

The development of angioplasty catheters and stents has opened a new venue for the treatment of intimal flaps $^{2}$. We report here the successful treatment with a Palmaz stent in the acute period of a traumatic intimal flap of the superficial femoral artery caused by gunshot trauma.

\section{CASE REPORT}

A 26-year-old male patient was admitted in the emergency room with a 4-hour history of gunshot wound to the left lower extremity. Clinical examination showed a small hematoma in the thigh and a bullet track close to the superficial femoral artery. All pulses were normal.

Duplex scan revealed an $8 \mathrm{~mm}$ intimal flap of the arterial wall without blood leakage, and the patient was brought to the vascular operating room. Anterograde puncture of the common femoral artery was performed. After injection of contrast media, the intimal flap was precisely confirmed and localized. No contrast extravasation was observed (Fig. 1).

A hydrophilic guide wire was introduced under fluoroscopy passing the intimal flap. A Palmaz stent P 294,

From the Division of Vascular Surgery, Hospital das Clínicas, Faculty of Medicine, University of São Paulo. mounted in a 6/30-mm angioplasty balloon, was placed in the desired position. The balloon was inflated and the stent expanded, correcting the intimal flap (Fig. 2).

One year after the operation a duplex scan revealed normal flow in the artery and complete exclusion of the intimal flap, distal pulses were palpable, and the patient was completely asymptomatic.

\section{DISCUSSION}

Little is known about the natural history of intimal flaps due to ethical constraints of doing controlled studies in humans. Consequently, several animal studies have been carried out in order to evaluate the natural history of this disease ${ }^{3}$.

There is a consensus in the literature that large arterial flaps have to be 


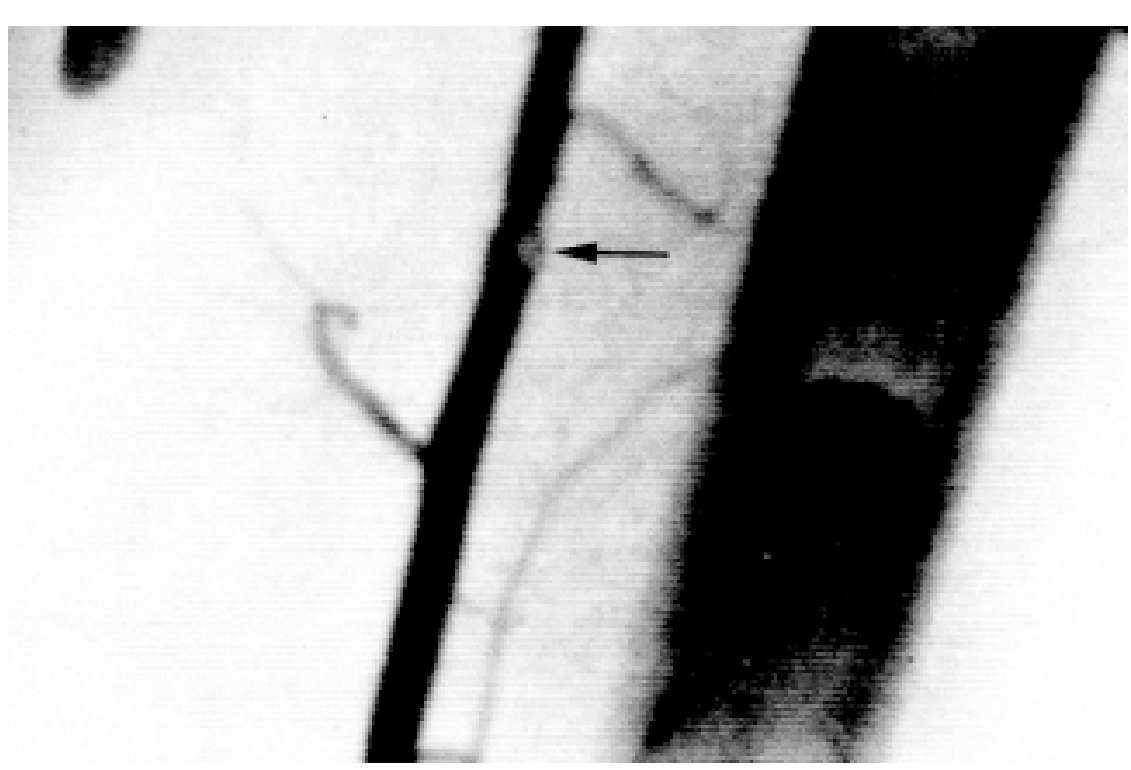

Figure 1 - Pre operatory arteriography showing intimal flap.

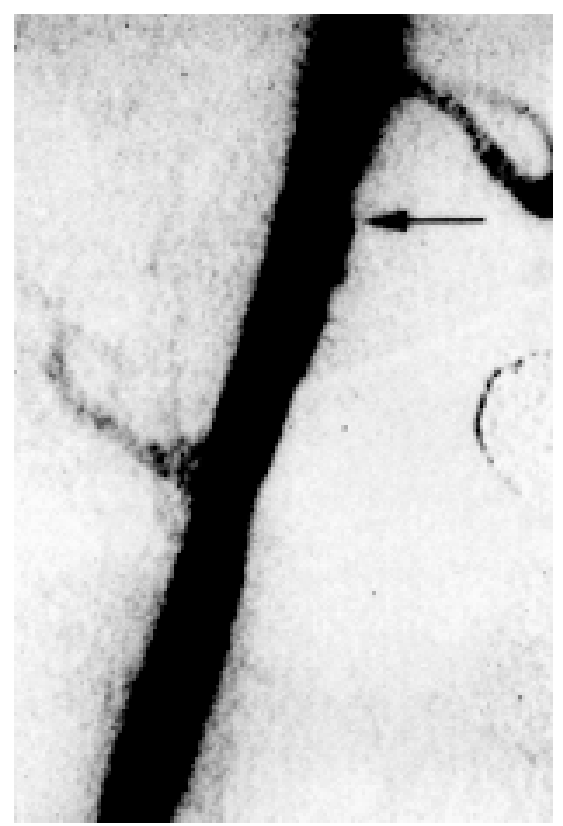

Figure 2 - Arteriography after stenting the intimal flap.

sult of arterial permeability after 1 year. The prompt treatment avoided acute arterial occlusions, which may be the natural course of these lesions, especially when large flaps are produced $^{9,10}$.

Henceforth, patients with intimal flaps might be brought to the vascular operating room that is equipped with digital fluoroscopy and a radiotransparent table, or to an interventional radiology room (with a stand-by operating room available). Under local anesthesia or radicular block, the patient would undergo angiography. Once the intimal flap is found, a stent could be introduced using the same access, and it could be placed where it would be expanded with the help of fluoroscopy, correcting the lesion. 
WOLOSKER N. e col. - Uso de "stents" no tratamento de lesões arteriais intimas de origem traumática: relato de caso. Rev. Hosp. Clín. Fac. Med. S. Paulo 56(4):119-122, 2001.

O tratamento de lesões arteriais íntimais de origem traumática é controversa pela sua evolução natural ser desconhecida. As opções terapêuticas atuais incluem reconstrução arterial e ob- servação clínica. A idéia da utilização de "stents" para a correção de descolamentos intimais é baseada no seu uso em dissecções, "flaps" e irregularidades da artéria após angioplastia com balão.

Descrevemos o tratamento bem sucedido de um descolamento de íntima da artéria femoral superficial causado por ferimento de arma de fogo com a utilização de um "stent" de Palmaz na fase aguda. Um ano após a implanta- ção do "stent", o duplex scan mostrou fluxo normal pela artéria com a exclusão completa do descolamento de íntima, com pulsos distais palpáveis e com o paciente completamente assintomático.

DESCRITORES: "Stents". Trauma de artéria femoral. Trauma vascular. Técnicas minimamente invasivas. "Stent" de Palmaz.

\section{REFERENCES}

1. PANETTA TF, SALES CM, MARIN ML et al. - Natural history duplex characteristics and histopathologic correlation of arterial injuries in a canine model. J Vasc Surg 1992;16:867-875.

2. CRIADO FJ, QUERAL LA \& PATTEN P - Endovascular surgery in daily practice: a re-appraisal. J Endovasc Surg 1994;1:92-99.

3. NEVILLE RF, HOBSON RW, WATANABE B et al. - A prospective evaluation of arterial intimal injuries in an experimental model. $\mathbf{J}$ Trauma 1991;31:669-675.

4. SAWCHUK AP, ELRUP-JORGENSEN J, TOBER MCCOY D et al. The natural history of intimal flaps in a canine model. Arch Surg 1990;125:1614-1616.
5. TUFARO A, ARNOLD T, RUMMEL $M$ et al. - Adverse outcome of nonoperative management of intimal injuries caused by penetrating trauma. J Vasc Surg 1994;(4):656-659.

6. WOLOSKER N, ROSOKY RMA, ANACLETO AM et al. - The use of stents in the treatment of intimal flaps: an experimental study. Vasc Surg 1999. (In press).

7. FREIMAN DB, FREIMAN MP, SPENCE RK et al. - Economic impact of transluminal angioplasty. Angiology 1985;36:772-777.

8. DILLARD BM, NELSON DL \& NORMAN HG Jr - Review of 85 major traumatic arterial injuries. Surgery 1968;63:391-395. 
9. FRYKBERG ER, VINES FS \& ALEXANDER RH - The natural history of clinically occult arterial injuries: a prospective evaluation. J Trauma 1989;29:577-583.
10. ROSE SC \& MOORE EE - Angiography in patients with arterial trauma: Correlation between angiographic abnormalities operative findings and clinical outcome. Am J Roentgenol 1987;149:613619.

Received for publication on March 01, 2001. 